\title{
Estimating the potential of roadside vegetation for bioenergy production
}

\author{
Alexey Voinov ${ }^{a,}$, Oludunsin Arodudu ${ }^{b}$, Iris van Duren ${ }^{a}$, Javier Morales ${ }^{a}$, Ling Qin ${ }^{a}$ \\ ${ }^{a}$ ITC, University of Twente, Hengelosestraat 99, Enschede, Netherlands \\ ${ }^{\mathrm{b}}$ Leibniz Centre for Agricultural Landscape Research (ZALF), Eberswalder Straße 84, 15374 Müncheberg, Germany
}

\section{A R T I C L E I N F O}

\section{Article history:}

Received 26 December 2014

Received in revised form

27 March 2015

Accepted 12 April 2015

Available online 22 April 2015

\section{Keywords:}

LCA

Willow

Grass

Rotation cropping

Efficiency

EROEI

\begin{abstract}
A B S T R A C T
The Netherlands, like other European Union countries, is under intense pressure to increase its national share of energy from renewable sources in accordance with 2020 Kyoto Protocol obligations. Bioenergy in this context is especially interesting because it can replace liquid fuels so much in demand for transportation. In Europe, due to high population density, and intensive use of limited land resources, sources of biomass are quite limited. This study examines the potential of road verge for biomass production. In this case there is no conflict with agricultural production - "food for fuel" conflict - and very little problems with natural conservation, since we are focusing on already disturbed and heavily used and polluted areas. The road verge is also easily accessible and in most cases already has to be maintained and cultivated. We use GIS (Geographical information system) to identify the total area of land along the roads in the Netherlands that can potentially be used for bioenergy purposes. We then consider the opportunities and constraints of cultivating various types of biomass, mainly focusing on grasses and willow, short rotation coppice, as biomass sources on the road verge. Based on that, we distinguish between areas that are unavailable due to safety requirements, areas that are conditionally available provided that current regulations are revised and areas that are already unconditionally available. We assess the entire production chain in terms of Energy Return on Energy Invested (EROEI), and consider various combinations of grass and willow operations for bioenergy production. Looking at several roads in Eastern Overijssel, we have estimated that there is approximately $4.24-4.68 \mathrm{ha} / \mathrm{km}$ of road verge conditionally available along highways, A-roads, and some $0.80-2.67 \mathrm{ha} / \mathrm{km}$ available along local roads, $\mathrm{N}$-roads. However, only $1.02-1.62 \mathrm{ha} / \mathrm{km}$ and $0.37-0.80 \mathrm{ha} / \mathrm{km}$ of $\mathrm{A}$ and $\mathrm{N}$ roads respectively are available unconditionally. The EROEI for some scenarios of both grass-based and willow-based production were quite high, $15-42$, making such use of road verge quite promising.
\end{abstract}

๑) 2015 Elsevier Ltd. All rights reserved.

\section{Introduction}

At present, coal and gas account for more than $50 \%$ of EU's electricity supply and will remain an important part of the energy mix (European Commission, 2007). However, the accelerating process of global warming, growing demand for energy, depletion of cheap fossil fuel supplies and environmental concerns are raising the significance of renewable energy (Luque et al., 2008). Over sixty

\footnotetext{
* Corresponding author. Tel.: +31 0633657124.

E-mail addresses: a.a.voinov@utwente.nl, aavoinov@gmail.com (A. Voinov), oludunsinarodudu@gmail.com, Oludunsin.Arodudu@zalf.de (O. Arodudu), vanduren@utwente.nl (I. van Duren), j.morales@utwente.nl (J. Morales), qinling2003@gmail.com (L. Qin).
}

percent of renewable energy in the Netherlands comes from biomass (Central Bureau of Statistics, 2009), which makes it the most popular renewable energy source in this country. Besides reducing greenhouse gases (GHG) emissions, biomass derived fuels are especially attractive because they can be easily stored and used as non-variable energy; same cannot be said of solar and wind power - the other most popular renewable energy sources (McKendry, 2002a; Demirbaş, 2005; Ölz et al., 2007).

The European Council in March 2007 endorsed a mandatory target of $20 \%$ share of energy from renewable sources in overall Community's energy consumption by 2020 (European Parliament and European Council, 2009). For the Netherlands, for example, the percentage of renewable energy in final energy consumption has to be increased from $3.4 \%$ in 2008 to targeted $14 \%$ in 2020 (a deficit of 10.6\%) (Europe's Energy Portal, 2010). Under this 
pressure, the Netherlands is expected to fully embrace every opportunity to develop its bioenergy potential. This may include wood and wood wastes from forests and industries, sewage sludge from wastewater treatment plants, organic waste from households, oils and fats from food industry, manure from dairy farms and crops specifically grown for bio-energy such as rapeseed (Brassica napus), willow (Salix), Miscanthus (Basu, 2010), etc.

Until recently, most energy crop cultivation was done on arable land. However, low energy efficiency of energy crops (Firrisa et al., 2013; van Duren et al., 2015) and lack of free arable land are major limitations for the cultivation of these crops in Europe, especially in the more densely populated and developed countries like the Netherlands. In general, for reasons of food security, it is preferable to leave agricultural land available for food production and find other sources of biomass for bioenergy production (Londo, 2002; Faaij et al., 1998). Arodudu et al. (2013, 2014) argue that bioenergy production should be mainly focused on the waste flows (urban waste, agricultural crop residue, manure, etc. as well as biomass produced on waste land such as construction lots, eroded lands, etc.) and that only then it can be conducted with sufficiently high efficiency. In this regards, the land along the roads appears as a kind of wasteland and is a promising area where biomass can be harvested for bioenergy needs with little or no conflict with other potential uses. In fact, we argue that producing biomass along the roads can be promising and beneficial from a variety of perspectives, including economy, traffic safety, esthetics, etc. Moreover, these areas are easily accessible and are directly linked to major transportation routes, which makes its cultivation and delivery of products more efficient.

The Netherlands ranks among the top 10 high road density countries in the world (Encyclopedia of the Nations, 2007). With a total of more than $137,000 \mathrm{~km}$ of roads, it has an average road density of $5 \mathrm{~km}$ per $\mathrm{km}^{2}$ of surface area (Visser, 2010). This indicates that there might be large areas of available road verge in this country. Easy access to this land is another advantage cutting the cost of harvesting and transportation of biomass. Haines-Young et al. (2000), Truscott et al. (2005) proved that vehicular activities can elevate the nitrogen concentration of road verges. This can reduce the fertilizer requirements for crop growth on the road verge. Huang's study (1987), furthermore confirmed that planting of shrubs in the median and road verge could stop errant vehicles in case of accident and absorb the impact, without doing much damage to the car. Also, the shrub barrier could reduce traffic noise and headlight glare (van der Heijden and Martens, 1982), contributing to sound environment and road safety. As with other biomass for bioenergy production, utilizing roadside biomass will provide for carbon sequestration, will encourage technological development and innovation, and offer opportunities for employment and regional development (Vollebergh, 1997; Volk et al., 2004). In this study, we have been mostly focusing on the Easternmost part of the Overijssel province in Netherlands, however our analysis and methods are quite general, and could be easily applied elsewhere and scaled up to the whole of Netherlands and beyond.

Road verges are maintained as transition zones between different land uses and in most cases appear as strips on both sides of the road. Road verges are mown to ensure visibility along roads in case of an accident, to enhance visibility of road signs and constructions (e.g. electricity boxes), to get rid of excessive nutrients in soils and for esthetic and maintenance purposes. For example, in Overijssel, the mowing policy recommends that road verges be mown twice a year. A maximum of $20 \mathrm{~cm}$ height of grass is allowed at the end of the 26th and 45th weeks (mowing weeks). The mowing exercise is preferably carried out in the evening to reduce possible negative effects on transportation (Rijkswaterstaat, 2008). In the Netherlands, municipal authorities are responsible for more than $90 \%$ of the Dutch roads while the national government is only responsible for $4 \%$ (Central Bureau of Statistics (2011)). The 4\% managed by the national government include all the motorways (A-roads) and a few national highways (N-roads); these are mown more regularly than other roads. Vegetation along these roads is currently managed by Rijkswaterstaat (Public Works Department), the executive body of the Ministry of Transport and Water (A. Reuver, personal communication, 7 October 2010). According to the "Overview of the vegetation along National Road" (Rijkswaterstaat, 2008), management of verge grasses involves choosing between different species types and different manual or automated methods for pruning, mowing, chipping and cutting. In reality, grass is the main target vegetation and a combined cutting and suction method is used to mow verge grasses. The Dutch environmental management act (2004) states that the removed grass must be delivered to and processed by a waste processor which has a valid license. Usually, the grass is either deposited to waste landfill or composted (J. W. Slijkhuis, personal communication, 5 November 2010; H. Nieuwenhuis, personal communication, 19 January 2011). However in all cases these operations are treated as an expense that should be preferably minimized (Van Strien et al, 2005). This attitude should be changed if the harvested biomass becomes treated as a valuable resource for bio-energy production.

Maximization of biomass cultivation in road verges requires choosing the most suitable crop species for the purpose, which would imply such characteristics as (Ponton, 2009):

- Ability to grow and reproduce at a very fast rate

- Ability to produce high yield

- Perennial nature

- Having little or no need for annual ploughing once planted

- Adaptability to marginal land

- Having minimal fertilizer requirement.

Some of these requirements are exactly opposite to the current practices of maintenance of the road verges. Since large trees along the road is a safety concern, feasible energy crops for road verges are restricted to small trees, shrubs and grasses (Faaij et al., 1998). Based on these reasons, energy crops suitable for road verge include:

- Short rotation woody crops, e.g. willow and poplar (Fischer et al., 2010; Zuwala, 2012; González-García et al., 2014)

- Perennial grasses, e.g. Miscanthus, switchgrass (Panicum virgatum), reed canary grass (Phalaris arundinacea) (Huisman, 2003).

Since perennial grasses have been largely treated before (e.g. Arodudu et al., 2013) in this study, where possible, we will focus more on willow short rotation coppice (SRC) as the biomass feedstock. Local clones of willow SRC have been well developed and observed in Europe. However, in the Dutch context, few trials have been carried out to study the biomass production of local clones (Kuiper, 2003; Bussel, 2006). Their studies suggest that for the Netherlands, productive local clones of willow SRC include Zw. Driebast (Salix triandra), Het Goor (Salix alba), Belders (Salix alba), Tora (Salix viminalis $x$ Salix schwerinnii), Bjorn (Salix viminalis $x$ S. schwerinnii), Black Spaniard (S. triandra), Loden (S. triandra) and Jorr (Salix viminalis). Despite the fact that certain clones produce more biomass than the others, it is recommended to mix different willow species and varieties for pest and disease prevention (Ramstedt, 1999; Londo et al., 2004).

Willow is well adjusted to the Dutch climate conditions (Gigler, 1999; Londo, 2002) and has a long history of cultivation in the Netherlands (Schepers et al., 1992). The biomass produced with willow SRC is potentially high. In Dutch conditions the productivity 
of certain local clones is $5.62-15.62$ tons of dry matter/ha/year (Bussel, 2006). Willow has a uniform texture of woody biomass, high initial growth, a short life span, easy reproduction by vegetative means (stem cuttings) and the ability to re-sprout vigorously after each harvest, which makes it very suitable for energy production (Weih, 2004). Furthermore, its cultivation requirements are low, it has few insect and pest problems, and considerably high biodiversity, which includes several rare and threatened red list species (Boosten, 2009). Another advantage is its wide range of genetic variability (Volk et al., 2009).

There are several constraints to the use of road verge as a land resource for cultivating biomass, especially if it is other than grass. The most important concern is road safety. To ensure road safety, certain road verges such as buffer zones around junctions and areas inside horizontal road curve must be free of obstacles. According to International Sight Distance Design Practices, "Intersection Sight Distance is intended to provide drivers at or approaching an at-grade intersection with an unobstructed view of the entire intersection and sufficient lengths of the intersecting highways to permit the approaching drivers to anticipate and avoid potential collisions" (Harwood et al., 1995). The Clear Sight Triangle is defined by sight distances along each approach of an intersection. For the Netherlands, policies of Intersection Sight Distance design are explicitly addressed in some official guidelines (Staatsuitgeverij, 1986), which are based on the prevailing 85th percentile of design speed. The Intersection Sight Distance along the major-road leg is decided according to different design speeds (Table 1 ).

The Intersection Sight Distance along the minor-road leg is defined as the distance from edge of road to the driver's eye, which is $5 \mathrm{~m}$ in the Netherlands (Fig. 1).

Furthermore, vegetation inside horizontal road curves may also obstruct the driver's line of sight. The value of Stopping Sight Distance is the same as for intersections (Table 1) because it takes the same distance to stop the vehicle under the same design speed (Eck and McGee, 2008). This is shown in Fig. 2.

According to Mr. J.W. Slijkhuis (personal communication, 5 November 2010), who is responsible for the greenery along most of the Provincial roads in the province of Overijssel, the length of grass vegetation and crops within $1.20 \mathrm{~m}$ from the edge of asphalt pavements (roads, parallel roads and bike paths) and in the Clear Sight Triangle should never exceed $0.50 \mathrm{~m}$. The $1.20 \mathrm{~m}$ buffer zone of road edge should also be kept clean for road signs.

There are two kinds of conflicts between bioenergy production and other land use types on the road verge. The first one occurs within the road verge, where land is already used for business (e.g., advertisement and electricity poles), transportation (e.g., water area, side walk, cycle way, sandy path), or conservation (e.g., forest, nursery) purposes. The second conflict appears on the border of road verge, where it is connected with different surrounding land uses such as residential (e.g., building, garden), agricultural and

\section{Table 1}

Intersection Sight Distance along the major-road types in the Netherlands. These define the Clear Sight Triangle where restrictions are imposed on the vegetation height.

\begin{tabular}{llll}
\hline Design situation & A-road & N-road & Other road \\
\hline $\begin{array}{c}\text { Design speed }(\mathrm{km} / \mathrm{h}) \\
\quad \text { (outside urban areas) }\end{array}$ & $120^{\mathrm{a}}$ & 100 & 80 \\
$\begin{array}{c}\text { 85th percentile of design } \\
\text { speed }(\mathrm{km} / \mathrm{h})\end{array}$ & 102 & 85 & 68 \\
$\begin{array}{c}\text { Intersection sight distance } \\
\text { along major road }(\mathrm{m})\end{array}$ & 250 & 150 & 100 \\
\hline
\end{tabular}

${ }^{a}$ As of 2013 the maximum allowed speed on some parts of Dutch A roads was increased to $130 \mathrm{~km} / \mathrm{h}$. It is yet to be seen if this will have any impact on the evaluations made here.

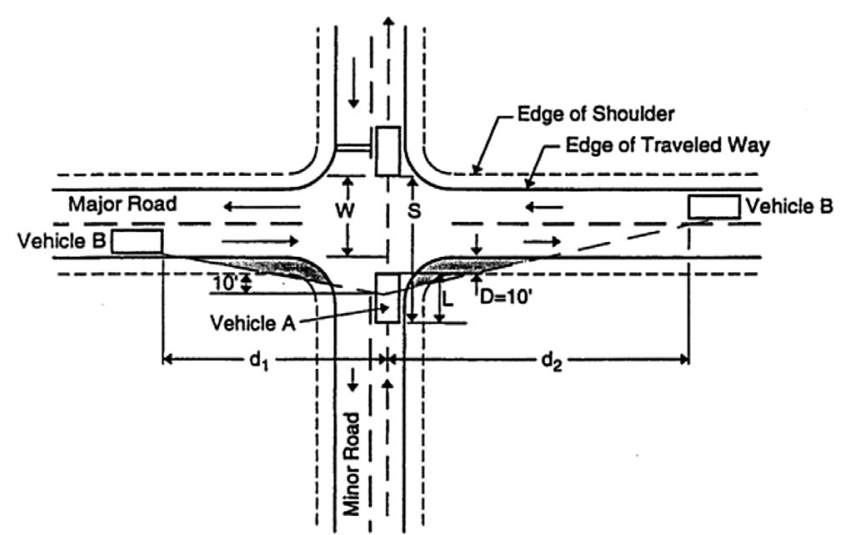

Fig. 1. Typical Clear Sight Triangle used in Intersection Sight Distance design. (Source: Harwood et al., 1999). Vegetation should not exceed $0.5 \mathrm{~m}$ in these areas.

recreational (e.g., playground, park), etc. For example, no dense tree-like vegetation is allowed to stand where the road crosses agricultural fields (A. Reuver, personal communication, 7 October 2010) as this would not fit in the surrounding cultural landscape. Similar conflicts with residential areas and recreational land should be avoided. These two conflicts can be avoided by preserving original land uses and adhering to laws preserving them in the event of using road verges for biomass cultivation.

The Forest Act of the Netherlands requires that logging of trees thicker than $8 \mathrm{~cm}$ be reported to the National Service of the Ministry of Agriculture and trees be replanted where it is felled or, if not possible, as close as possible to compensate the original habitat. Rijkswaterstaat has an agreement with the Ministry of Agriculture on implementation of the Forest Act (Rijkswaterstaat \& Dienst Weg-en Waterbouwkunde, 2006). Therefore, in order to cut down existing trees along roads, a logging permit is usually requested from local municipality, except for those emergencies such as car accident, storm and disease. Thinning of shrubs is not restricted by the law (Rijkswaterstaat and Dienst Weg-en Waterbouwkunde, 2006; Ministerie van LNV, 2000). However, the province of Overijssel is trying to improve safety on the road verge by cutting down trees at various locations (Provincie Overijssel, 2010), which indicates that some parts of the forested road verge can become available as land resource for biomass cultivation.

According to the Code of Green Management Service (Borst and Sprong, 2006), certain amount of species along Dutch roads are under protection. There are three levels of conservation: general

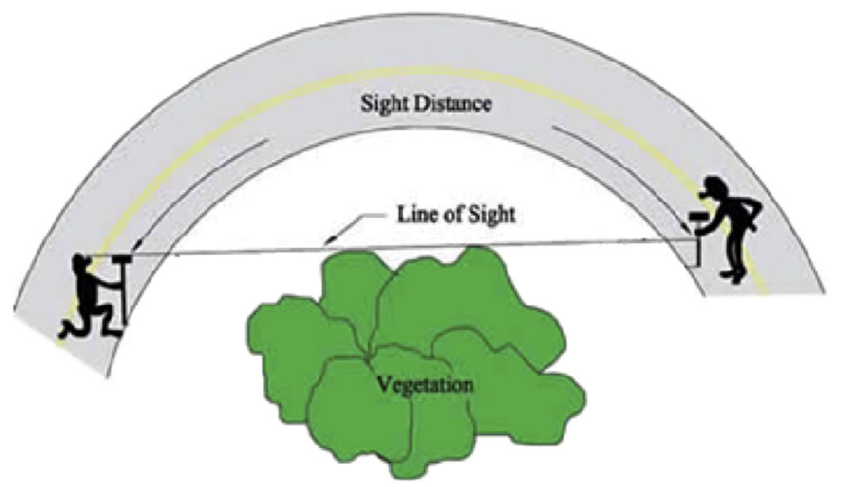

Fig. 2. Stopping Sight Distance on horizontal road curves (Source: Eck and McGee (2008)). Here also vegetation higher than $0.5 \mathrm{~m}$ is not allowed. 
protection, special protection and bird protection. It is forbidden to pick, collect, cut, stab, destroy, damage, uproot or remove those protected species from their habitat. Therefore, selective mowing strategy has to be applied. An alternative way for ensuring this species conservation is sparing other marginal land for natural conservation. There are at least two arguments against the idea of saving road verge for ecological protection. The soils of road verge are usually polluted by vehicle exhaust, containing heavy metals such as Cd, Cu, Pb and Zn (Warren and Birch, 1987), and the roadside environments are highly disturbed by traffic (Cuperus et al., 1996). Gommers et al. (2005) even suggests that it is particularly suitable to establish willow SRC on heavy-metal-contaminated land because of its soil-to-wood transfer of pollutant. This of course may require further treatment of exhaust for heavy metals when the biofuels are incinerated.

This study evaluated different energy crops to determine a potential vegetation mix for producing bioenergy on the road verge without compromising road safety, land use conflicts and ecological concerns. It also conducted a Life Cycle Assessment (LCA) to determine the overall energy efficiency of cultivating the most suitable biomass types on the road verge. This included an inventory of all the processes involved from site preparation of the road verges to the direct combustion of the biomass for electricity and/or combined heat and electricity generation at the biomass power plant, or gasification of grass biomass for electricity and/or combined heat and electricity production.

\section{Methods}

As required by ISO 14040 standard for performing LCA the definition of boundaries for this study includes a description of the study area, the road networks examined within the study area and the energy performance index used in evaluating the bioenergy potential of the study area. As a proof of concept, we have chosen a relatively small area consisting of six municipalities in the East of Netherlands (Dinkelland (Denekamp), Enschede, Haaksbergen, Hengelo, Losser and Oldenzaal) with a total area of $608.44 \mathrm{~km}^{2}$ (Fig. 3). The road network in this area represents all the main types of roads in the country (as well as in Europe in general). There are two A-roads and eighteen N-roads in this area, which represent motorways and national highways, respectively, according to the Dutch road numbering system (Table 2). For the A-roads the road verges are managed by the Rijkswaterstaat East Netherlands. Most of the one-lane N-roads except N18 and N35 are maintained by the provincial greenery office of Overijssel (J.W. Slijkhuis, personal communication, 5 November 2010). For this study we have further narrowed our scope and have focused only on the roads that are under the Rijkswaterstaat authority, that is A1, A35, N18 and N35. The functional unit for our analysis will be a hectare of road verge per which we will be making our estimates.

The energy efficiency was measured as return on energy invested (EROEI). It is calculated as the ratio of the energy output (expected return) obtained from a particular energy production activity to the energy input (investment required) required to get that energy (Cleveland et al., 1984; Hall et al., 2009):

EROEI $=$ Expected Energy Output/Required Energy Investment

To calculate the EROEI we have developed a Life Cycle Inventory (LCI) taking into account all the direct and indirect energy costs and outputs incurred along the energy production chain.

This started with the identification of all the areas along the different roads in the study area that are potentially available for biomass production. Information about relevant road verge management regimes, practices, regulations and constraints was derived from literature and Rijkswaterstaat, the management authority of Dutch road verges. Datasets on the road networks and verges were taken from cadastral data available at http://www. kadaster.nl/ and the Rijkswaterstaat East Netherlands. Area of road verges available for cultivation of willow were estimated by first putting into consideration all the necessary constraints as defined by Rijkswaterstaat East Netherlands. These included:

\section{- Road safety issues}

- Clear Sight Triangle of intersections on both A \& N road (the Intersection Sight Distance along major-road leg is $250 \mathrm{~m}$ for A-road, $150 \mathrm{~m}$ for $\mathrm{N}$ road and the Intersection Sight Distance along minor-road is $5 \mathrm{~m}$ for all the roads);

- Clear sight area of horizontal curves of A-road (with the design speed of $120 \mathrm{~km} / \mathrm{h}$ on A-roads, the stopping sight distance is $250 \mathrm{~m}$ );

- $1.2 \mathrm{~m}$ buffer zone of road edge of both $\mathrm{A}$ and $\mathrm{N}$ road is to be kept clean for road signs;

- Intermediate zone of a two-way road (is usually narrow and should be kept free of obstacles so that drivers are able to observe vehicle condition on the opposite side. However, these areas can still be considered available for grass as long as the height of grass does not exceed $0.50 \mathrm{~m}$ ).

- Land use conflicts (that may prevent planting willow, but in some cases may be resolved with owners)

- Within road verge (Transportation - water area, side walk, cycle way, sandy path; and Business - advertisement or electricity pole)

- On border of road verge (Residence - building, garden; Agriculture; Recreation - playground, park.

- Ecological restrictions (that forbid to pick, collect, cut, stab, destroy, damage, uproot or remove protected species, which are on the list recognized by Rijkswaterstaat (Borst and Sprong, 2006)) that specifies

- Locations of protected species;

- Locations of recorded trees.

While the road safety constraints are quite strict, the other two types, land use and ecological restrictions, are often negotiable. For example, in some cases it may be shown to adjacent landowners or to conservationists that planting willow can be even more beneficial for them than having mowed grass strips along roads. Therefore we have defined two types of land availability:

\section{- Unconditional - land available, none of the above restrictions} apply;

- Conditional - land may be available if land use or ecological constraints are negotiated.

In other words, unconditionally available land includes the land along the road verge except the areas that are restricted by safety issues and by land use and ecological concerns. This land that may be restricted by land use and ecological concerns is considered to be conditionally available.

To identify and quantify the land available for energy production inside the verge areas of the selected $\mathrm{N}$ and $\mathrm{A}$ roads (See Table 2), first, we developed a set of spatial query functions that capture the conditions placed by road safety, land use, and ecological concerns. These constraint functions were constructed using sequences of standard SQL spatial operators, where each sequence relied on a set of conditional statements to comply with the specifications prescribed by law (see above). Then, the resulting functions were applied to the road and verge datasets to 


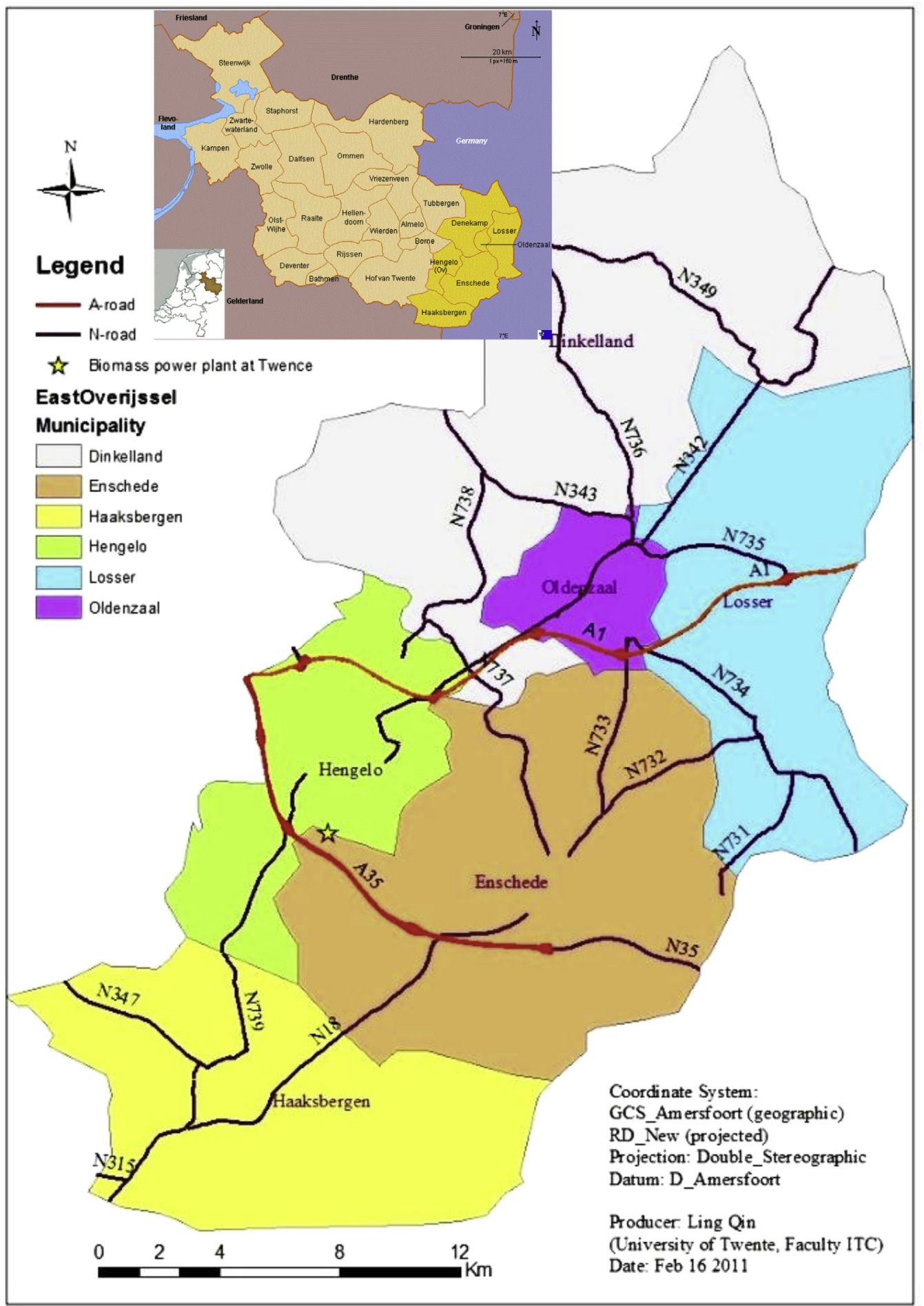

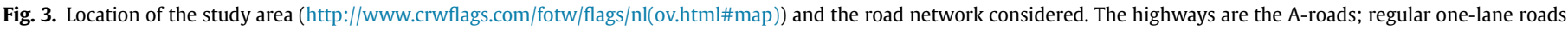
are the $\mathrm{N}$-roads.

filter out off-limit areas. Next, a series of summary queries were executed to classify suitable areas as conditionally and unconditionally available, discriminated by exiting vegetation types. And finally, we derived the values corresponding to area per kilometer of road that can be used for energy production, so that estimations of available area along every road could be made. An example of the result of using these spatial operations can be seen below in Fig. 6.
Knowing the total available area, we can turn to the analysis of energy invested and produced under various scenarios of biomass production. We will consider the following scenarios:

1. Harvesting verge grass on all the area available;

2. Growing willow on unconditionally available land;

3. Growing willow on unconditionally and conditionally available land. 
Table 2

Length of $\mathrm{A}$ and $\mathrm{N}$ roads in the study area.

\begin{tabular}{llc}
\hline No. & Road number & Length $(\mathrm{km})$ \\
\hline 1 & A1 & 27.12 \\
2 & A35 & 19.51 \\
Total & A-roads & $\mathbf{4 6 . 6 3}$ \\
3 & N18 & 18.4 \\
4 & N315 & 1.0 \\
5 & N342 & 34.7 \\
6 & N343 & 9.2 \\
7 & N346 & 0.4 \\
8 & N347 & 8.0 \\
9 & N349 & 12.5 \\
10 & N35 & 5.6 \\
11 & N731 & 5.1 \\
12 & N732 & 6.2 \\
13 & N733 & 8.8 \\
14 & N734 & 11.8 \\
15 & N735 & 5.8 \\
16 & N736 & 10.1 \\
17 & N737 & 10.2 \\
18 & N738 & 8.2 \\
19 & N739 & 14.6 \\
20 & N743 & 1.5 \\
Total & N-roads & $\mathbf{1 7 2 . 1}$ \\
Total & N18 +35 & $\mathbf{2 3 . 9 3}$ \\
\hline
\end{tabular}

To estimate the yields and energy requirements for verge grass, we used the methodology and numbers developed by Arodudu et al., 2013 (8 ton dry matter (DM) ha $\mathrm{hr}^{-1}$ of grass, when harvested twice annually) and Grisso et al., 2010 (energy for mowing and collection of grasses with tractor mounted forage harvester $0.80-1.06 \mathrm{GJ} / \mathrm{ha}^{-} \mathrm{yr}^{-1}$ ) for the cases when natural grasslands are for bioenergy production.

Here we will focus more on the processes associated with cultivation, harvest and processing of biomass from willow. The production chain of willow SRC includes the following stages (Fig. 4), which are all associated with certain energy investments (Caslin et al., 2010; DEFRA, 2004):

$>$ Site preparation - mowing and removing existing vegetation;

$>$ Establishment - planting (twin rows $0.75 \mathrm{~m}$ apart, with $1.5 \mathrm{~m}$ between each set of twin rows) and cutback (cutting to $10 \mathrm{~cm}$ of

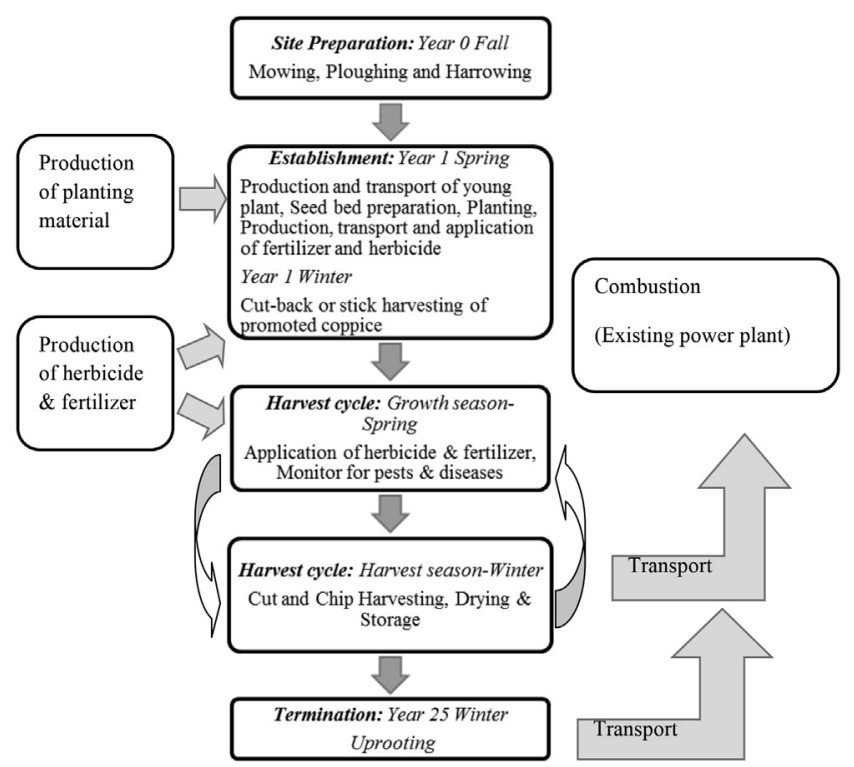

Fig. 4. Major activities in the production chain of a willow short rotation plantation (Source: DEFRA (2004); Caslin et al. (2010)). All these require energy investments, which are accounted for in Table 3. ground level to promote the development of multi-stemmed coppice).

$>$ General management - fertilization (150-400 kg N ha ${ }^{-1}$ per three year rotation or less due to elevated levels of $\mathrm{N}$ on road verge), weed control $(2.25 \mathrm{~kg} / \mathrm{ha}$ year of herbicide Matthews, 2001)

$>$ Harvesting - a sustainable annual biomass yield of 12-14 oven dry ton per ha can be expected (Ceulemans et al., 1996; Caslin et al., 2010; Boosten, 2009; DEFRA, 2004). Willow is normally harvested every 2 or 3 years and can remain viable for 25-30 years. The shoots of willow can reach up to $6-8 \mathrm{~m}$ at the end of a three year harvesting cycle (DEFRA, 2004; Caslin et al., 2010). The maximal diameter that a harvest machine can handle is 60-70 $\mathrm{mm}$ (Nordh and Dimitriou, 2003), which is unlikely to be exceeded in the Netherlands. Generally, willow at harvest have a moisture content of $45-60 \%$, which needs to be reduced below 15\% for higher conversion efficiency (Faaij et al., 1997; Tubby and Armstrong, 2002). The two most common harvesting methods are:

o Stick harvesting: whole stems of willow are cut and chipped using cut and chip harvesting technology and then transported to conversion plant.

- Cut and chip harvesting: willow is cut and chipped fresh in a single pass, therefore, the quality of chips are much better than chipping dried bundles, and the power requirement for chipping operation is minimized. However, the harvested chips will self-heat quickly due to natural degradation and must be dried artificially immediately to eliminate the energy input for drying (Caslin et al., 2010).

$>$ Transportation - delivery of willow biomass from field to conversion plant. Here again we can use GIS operations to estimate the distance required to deliver the biomass to the processing units.

$>$ Termination - assumed by this study to occur 25 years after planting. The stools are either allowed to shoot or are ploughed prior to winter to allow early re-seeding in the following spring (DEFRA, 2004)

The energy investments required for willow cultivation and biomass production are presented in Table 3. Willow biomass can be converted into energy via two different forms of technologies: the thermo-chemical and the bio-chemical/biological technologies (McKendry, 2002b; Ni et al., 2006). Implementations of thermo-chemical technologies include combustion, pyrolysis and gasification processes; while examples of bio-chemical conversion include digestion (mono-digestion and co-digestion) and fermentation (McKendry, 2002b). The advantages of thermochemical technologies lies in their shorter reaction time (Bridgewater, 2001), and their better ability in destroying most organic materials, thereby ensuring a higher efficiency (Jenkins et al., 1998). The main processes, intermediate and end products of thermo-chemical conversion are illustrated in Fig. 5. The energy stored in biomass can be released as heat by direct combustion/ co-firing, or transformed into solid (e.g., charcoal) or gaseous (e.g., synthetic gas) fuels via pyrolysis or gasification under different utilization purposes.

Various ways of producing ethanol, hydrogen or biogas from specific energy crops have been identified in recent years (Demirbaș, 2007; Kim and Dale, 2005; Gray et al., 2006; Petersson et al., 2007; Börjesson and Mattiasson, 2008; Berglund and Börjesson, 2006; Börjesson and Tufvesson, 2011; Nguyen et al., 2013; Kumar et al., 2015), however, none of these conversion processes are of particularly high efficiency. This is because converting crops from its original solid form to liquid or gas greatly increases the energy processing demand (Ponton, 2009). 
Table 3

Energy investment in the production chain of willow SRC. When using nitrogen fertilizer the overall energy efficiency of the process can dramatically decrease.

\begin{tabular}{|c|c|c|}
\hline Activity & $\begin{array}{l}\text { Primary energy } \\
\text { investment } \\
\left(\mathrm{GJ} \mathrm{ha} \mathrm{h}^{-1}\right)\end{array}$ & Notes \\
\hline \multicolumn{3}{|l|}{ Site preparation } \\
\hline Mowing and collection ${ }^{a}$ & $0.80-1.06$ & Reference system \\
\hline Soil preparation ${ }^{\mathrm{b}}$ & 2.05 & $\begin{array}{l}\text { Energy requirement for } \\
\text { ploughing and harrowing }\end{array}$ \\
\hline \multicolumn{3}{|l|}{ Establishment } \\
\hline Cutting $^{\mathrm{b}}$ & 4.99 & $\begin{array}{l}\text { Energy requirement for } \\
\text { production and transport } \\
\text { of planting material }\end{array}$ \\
\hline Planting ${ }^{\mathrm{b}}$ & 1.11 & \\
\hline Cut-back (stick harvesting) ${ }^{\mathrm{c}}$ & $0.22-0.40$ & $\begin{array}{l}\text { Energy for cut and chip } \\
\text { harvesting }\end{array}$ \\
\hline \multicolumn{3}{|l|}{ Management } \\
\hline Herbicides $^{\mathrm{b}}$ & 1.20 & $\begin{array}{l}\text { Production and transport } \\
\text { of herbicides }\end{array}$ \\
\hline Herbicides $^{\mathrm{b}}$ & 0.26 & Application of herbicides \\
\hline $\mathrm{N}$ fertilizer ${ }^{\mathrm{b}}$ & 67.55 & $\begin{array}{l}\text { Production and transport } \\
\text { of fertilizer }\end{array}$ \\
\hline $\mathrm{N}$ fertilizer ${ }^{\mathrm{b}}$ & 0.84 & Application of fertilizer \\
\hline \multicolumn{3}{|l|}{ Harvesting } \\
\hline Harvesting ${ }^{\mathrm{c}}$ & $0.43-0.80$ & $\begin{array}{l}\text { Energy requirement for } \\
\text { combined cut and chip } \\
\text { harvesting, }\end{array}$ \\
\hline $\begin{array}{l}\text { Natural drying and } \\
\text { storage (approximately } \\
\text { the same for first } \\
30 \text { tonnes) }^{\mathrm{e}}\end{array}$ & $0.32-0.40$ & $\begin{array}{l}\text { Energy requirement for } \\
\text { emptying, front-loading } \\
\text { and dumping chips in the } \\
\text { storage barns }\end{array}$ \\
\hline Transportation $(15 \mathrm{~km})^{\mathrm{b}, \mathrm{d}}$ & 1.08 & \\
\hline Termination $^{\mathrm{b}}$ & 6.65 & \\
\hline \multicolumn{3}{|c|}{$\begin{array}{l}\text { a } \text { (Grisso et al., 2010). } \\
\text { b }(\text { Bussel, 2006). } \\
\text { c (Lechasseur and Savoie, 2005). } \\
\text { d (Van Strien et al., 2005). } \\
\text { e (Meyer et al., 2014). }\end{array}$} \\
\hline
\end{tabular}

Furthermore, current costs of these energy products (e.g., ethanol) are not competitive enough when compared to those of fossil fuel products (McKendry, 2002b). On the other hand, low cost, high reliability, well understood process and commercial availability of combustion makes it the most widely used thermochemical conversion technology. It contributes over $97 \%$ of bioenergy production all over the world (Ni et al., 2006).

Most energy return or output from thermo-chemical technologies are usually based on oven dry material at $0 \%$ moisture content. Varying figures are reported by different authors, mostly within the range of 16-20 GJ per oven dry ton (Börjesson, 1996; Heller et al., 2003; Kuiper, 2003; Lettens et al., 2003). However, since we deal with wet biomass, the process of natural drying can only reduce the moisture content to $25 \%$, while further drying still requires some

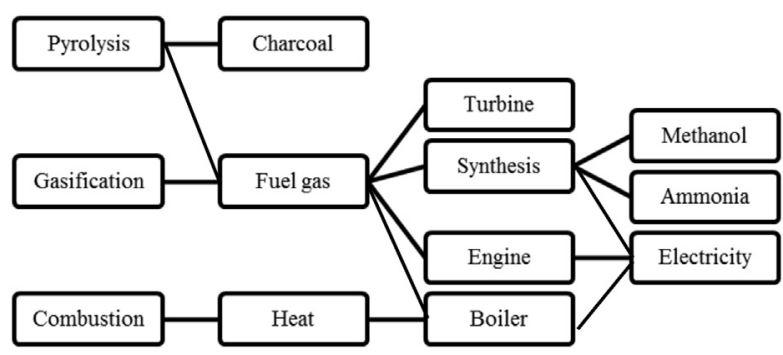

Fig. 5. Main processes, intermediate and end products of thermo-chemical conversion of willow (Source: Bridgewater and Peacocke (2000)). Electricity, charcoal, chemicals and heat are the main potential products. Energy efficiency for various products will vary. more energy inputs (AEA Energy and Environment, 2008). The Net Heating Value which takes into account moisture content and hydrogen content can be calculated by Milne equation (Faaij et al., 1997; Energy Research Centre of The Netherlands (1998)):

$\mathrm{LHV}=\mathrm{HHV}_{\mathrm{dry}} \times(1-\mathrm{W})-\mathrm{EW} \times\left[\mathrm{M}_{\mathrm{H} 2 \mathrm{O}} \times \mathrm{H} \times(1-\mathrm{W})+\mathrm{W}\right]$

where LHV: Lower Heating Value (Net Heating Value) of material received at the conversion plant, $\mathrm{HHV}_{\mathrm{dry}}$ : Higher Heating Value of dry material, W: moisture content, $\mathrm{H}$ : hydrogen content (wt\% of dry fuel), Ew: energy required for evaporation of water $(2.442 \mathrm{MJ} / \mathrm{kg})$, $\mathrm{M}_{\mathrm{H} 2 \mathrm{O}}$ : weight of water created per unit of hydrogen $(8.936 \mathrm{~kg} / \mathrm{kg})$.

The Total Energy Return is then calculated as:

$\mathrm{TE}=\mathrm{Pe} \times \mathrm{LHV}$

where Pe is plant efficiency. Table 4 presents the parameters used in our study to calculate the energy return from willow and verge grass. The lower plant efficiency value corresponds to production of electricity only, while the higher efficiency is attained when heat and electricity production are combined through the gasification process.

To conclude, in Table 5 we present the main assumptions used in this study for willow cultivation, while in Table 6 we describe the parameters of the three options for willow production that we will compare. Willow cultivation option 1 assumes no fertilizer or herbicide input, and short rotation length. Option 2 adds herbicide application alone (no fertilizer application), and finally in option 3 both fertilizer and herbicide are used, together with a long rotation length.

Overall, five options are considered in this study: the current system, i.e. mowing, transporting and dumping verge grass biomass at the composting plant at Twence twice a year (which is the existing practice for road verge maintenance - mown verge grass in the study area does not have any energy output based on this practice - therefore EROEI $=0$ ); the potential reference system, that uses the verge grass mown twice annually to produce electricity and/or combined heat and electricity through the gasification process; and the three willow cultivation options described above (1-without fertilizer and herbicide, 2-with herbicide and without fertilizer, 3-with both fertilizer and herbicide).

\section{Results and discussions}

In what follows, we are applying the methodology described above to the case study in Overijssel.

\subsection{Energy Return on Energy Invested}

The energy inputs of different activities in the four cultivation options are estimated in Table 7 (energy for mowing, transport, natural drying \& storage, and cut and chip harvesting per unit received biomass per hectare cultivated over a 25 year period). The EROEI of the three willow cultivation options and grass was then estimated from the energy inputs and energy return. From the result of the relative total energy input obtained (comparing the total energy input of the reference system potential i.e. gasification of verge grass for electricity and/or combined heat and electricity generation, to that of the three willow cultivation options Table 6), only the combustion of willow harvested for production of electricity or combined heat and electricity, on a two-year short rotation cycle without the application of fertilizers and herbicides during cultivation has a lower energy input than that of gasification of mown verge grass for production of electricity and combined 
Table 4

Parameters on energy return for willow and verge grass. Cogeneration of heat and electricity can almost triple the energy output and should be certainly recommended as the most efficient process.

\begin{tabular}{lll}
\hline Parameters & Willow & Verge grass \\
\hline HHV dry $(\mathrm{MJ} / \mathrm{kg}$ ) & $19.6^{\mathrm{b}}$ & $18.0^{\mathrm{a}, \mathrm{b}}$ \\
Moisture content at harvest (\%) & $50^{\mathrm{c}}$ & $60^{\mathrm{a}, \mathrm{c}}$ \\
Moisture content as received & $25^{\mathrm{c}}$ & $25^{\mathrm{d}}$ \\
$\quad$ & \\
$\quad$ at the conversion plant (\%) & $5.7^{\mathrm{b}}$ & $5.6^{\mathrm{b}}$ \\
Hydrogen content (\% of dry fuel) & $13.2^{\mathrm{a}, \mathrm{b}}$ & $12.0^{\mathrm{a}, \mathrm{b}}$ \\
LHV ar (MJ/kg) & $27-75^{\mathrm{c}, \mathrm{d}}$ & $35-75^{\mathrm{c}, \mathrm{d}}$ \\
Plant efficiency (\%) & $3.6-9.9^{\mathrm{c}, \mathrm{d}}$ & $4.2-9.0^{\mathrm{c}, \mathrm{d}}$ \\
Gross energy obtainable per biomass & & \\
$\quad$ as received (GJ/t) & & \\
\hline a (Faaij et al., 1997). & & \\
b (Energy Research Centre of the Netherlands, 1998). & \\
c (AEA Energy and Environment, 2008). & \\
d (Twence, 2009). &
\end{tabular}

heat and electricity, over the 25 year period; other willow options have higher inputs due to the application of fertilizers and/or herbicides, and the relative large amount of energy for mowing and collection of verge grass twice annually respectively. The dumping of verge grass mown twice annually at composting sites, as presently practiced (reference system) is a total waste in terms of energy, and should probably be discontinued if we are serious about reaching the $\mathrm{CO}_{2}$ reduction targets.

Also from the results obtained (Table 7), the willow cultivation option 1 (combustion of willow harvested for production of electricity or combined heat and electricity, on a two-year short rotation cycle without the application of fertilizers and herbicides) has the highest and most sustainable EROEI values (17.5-41.8), followed by willow cultivation option 2 (combustion of willow harvested on a two-year short rotation cycle without using fertilizer, but with herbicides during cultivation) (14.6-36.4). However, willow cultivation option 2 has a higher NEG (net energy gain) value than willow option 1 (willow cultivation option $1=624.6-1778.0 \mathrm{GJ} / \mathrm{ha}$, vs. willow cultivation option $2=771.2-2214.4 \mathrm{GJ} / \mathrm{ha}$ ). This is because willow option 2 compensated enough and returned some more energy on the energy it invests into herbicide production, transportation and application.

Willow cultivation option 3 (combustion of willow harvested for production of electricity or combined heat and electricity, on a threeyear short rotation cycle with application of fertilizer and herbicides during cultivation) had the lowest and most unsustainable EROEI and NEG values (EROEI: 1.0-2.7, NEG: $-11.11-1119.8 \mathrm{GJ} / \mathrm{ha}$ ). This is

Table 5

Common settings of four willow cultivation options.

\begin{tabular}{ll}
\hline Options & Assumptions \\
\hline Mixture of willow varieties & Zw. driebast, Het Goor, Belders, Tora, \\
& Bjorn, Black Spaniard, Loden and Jorr \\
Planting density & 18,000 ha $^{-1}$ \\
Final established density & 15,000 ha $^{-1}$ \\
Biomass yields & Remains the same from the 2nd harvest \\
& cycle to the last one, but the yields of the \\
& 1 st cycle (harvested sticks)were assumed \\
& to be 50\% of the usual yield \\
& 25 yr \\
Lifetime of cultivation & Stick harvesting \\
Harvesting & Natural drying in the field \\
Drying & at field \\
Chipping location & at harvest = 50\%; after drying = 25\% \\
Moisture content by weight & Biomass power plant at Twence: \\
Conversion process & combustion of biomass to generate \\
& electricity, or combined heat and electricity \\
& production. \\
\hline
\end{tabular}

\section{Table 6}

Four scenarios for road verge cultivation. The current scenario assumes collecting and composting the grass with no energy generation. The reference scenario assumes that grass is collected and used to produce electricity and heat, and the three other scenarios assume that willow is cultivated under different combinations of fertilizer and herbicide applications.

\begin{tabular}{|c|c|c|c|c|}
\hline Cultivation option & Reference & 1 & 2 & 3 \\
\hline $\mathrm{N}$ Fertilizer input $\left(\mathrm{kg} \mathrm{ha}^{-1} \mathrm{yr}^{-1}\right)$ & 0 & 0 & 0 & 60 \\
\hline Herbicide input $\left(\mathrm{kg} \mathrm{ha}^{-1} \mathrm{yr}^{-1}\right)$ & 0 & 0 & 2.25 & 2.25 \\
\hline Rotation length (yr) & 0.5 & 2 & 2 & 3 \\
\hline Harvesting cycle & 24 & 12 & 12 & 8 \\
\hline $\begin{array}{l}\text { Yield (moisture content }=50 \%) \\
\quad\left(\mathrm{t} \mathrm{ha}^{-1} \mathrm{yr}^{-1}\right)\end{array}$ & 8 & 16 & 20 & 24 \\
\hline
\end{tabular}

because the huge energy investments in fertilizers and herbicides are not returned or justified by the yield gains harvested every three years. The application of fertilizer and herbicides for increase in yield and harvest under the 3-year rotation cycle is therefore needless and should be jettisoned in the study area, because it might even be counter-productive (having EROEI of less than 1 and a negative NEG means that more energy is invested than obtained). To put these EROEI values in context we have collected some other results on efficiency of energy production in Table 8.

Although, reference system potential i.e. the gasification of verge grass for production of electricity and combined heat and electricity is less energy gainful and efficient in terms of NEG and EROEI (NEG: 776.5-1745 GJ/ha, EROEI: 16.5-32.6) compared to that of willow cultivation options 1 (NEG: 624.62-1779.84 GJ/ha, EROEI: 17.5-41.8) and willow cultivation options 2 (NEG: 771.24-2214.4 GJ/ha, EROEI: 14.59-36.37); it is still much more energy gainful and efficient than willow cultivation options 3 (NEG: -11.1-1119.8 GJ/ha, EROEI: 1.0-2.7). Besides it is more likely that grass can be grown on conditionally available lands. In the event of policy constraints that do not favor the planting of willow on roadside soils as envisaged based on results from this study, it should be accorded utmost priority to prevent wasting valuable biomass and bioenergy resources as it is presently done under the existing practices (dumping on compositing sites), with EROEI value of zero and negative NEG. Although, the willow cultivation option 1 and willow cultivation option 2 looks quite desirable and attractive, in reality, the EROEI can only be maintained over the 25-year cycle, if and only if the harvest yield is maintained and/or sustained. Although a handful of researches endorse the view that pollutants from traffic on the road supplies diversity of nutrients that is good enough for supporting willow cultivation (Warren and Birch, 1987; Cuperus et al., 1996; Gommers et al., 2005), doubts still exists, if the harvest yield can be maintained over a 25 year period, under intensive 2-year rotational harvest cycles without need for fertilizers periodically. Since fertilizer is the largest single energy investment in the life cycle of willow cultivation (constituting 91.68-92.24\%), its application for harvest yield maintenance somewhere over the two-year rotation cycles for a 25 -year period will have huge implications for the future sustainability of present EROEI and NEG values for willow cultivation on roadside soils.

\subsection{Areas available for production}

The total area of road verges unconditionally available (without any constraints) along the four roads examined under this study is 70.63 ha; while the total area of road verges available conditionally (based on negotiation of biodiversity or ecological constraints) is 168.58 ha (Table 9). A sample map showing unconditionally and conditionally available road verges in the study area as obtained from the GIS analysis can be found in Fig. 6. We may also derive that 
Table 7

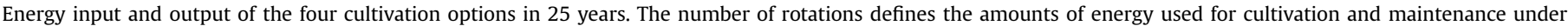
different scenarios.

\begin{tabular}{|c|c|c|c|c|c|c|c|}
\hline \multicolumn{4}{|l|}{ Cultivation option } & \multirow{3}{*}{$\begin{array}{l}\text { Reference (grass) } \\
\text { Energy input } \\
\text { GJ/ha }\end{array}$} & \multirow{3}{*}{$\begin{array}{l}1 \text { (willow - natural) } \\
\text { Energy input } \\
\text { GJ/ha }\end{array}$} & \multirow{3}{*}{$\begin{array}{l}2 \text { (willow with } \\
\text { herbicides) } \\
\text { Energy input } \\
\text { GJ/ha }\end{array}$} & \multirow{3}{*}{$\begin{array}{l}3 \text { (willow with } \\
\text { herbicides and fertilizers } \\
\text { on } 3 \text { yr rotation) } \\
\text { Energy input } \\
\text { GJ/ha }\end{array}$} \\
\hline \multirow[t]{2}{*}{ Activity } & \multicolumn{3}{|c|}{$\begin{array}{l}\text { No. of times in } 25 \text { years } \\
\text { (rotation) }\end{array}$} & & & & \\
\hline & $0.5 \mathrm{yr}$ & $2 \mathrm{yr}$ & $3 y r$ & & & & \\
\hline Mowing and collection & 25 & 1 & 1 & $20-26.5$ & $0.80-1.06$ & $0.80-1.06$ & $0.80-1.06$ \\
\hline Soil preparation & & 1 & 1 & & 2.05 & 2.05 & 2.05 \\
\hline Cutting production & & 1 & 1 & & 4.99 & 4.99 & 4.99 \\
\hline Planting & & 1 & 1 & & 1.11 & 1.11 & 1.11 \\
\hline Cut-back & & 1 & 1 & & $0.22-0.40$ & $0.22-0.40$ & $0.22-0.40$ \\
\hline Herbicides $^{\mathrm{a}}$ & & 0 & 9 & & 0.0 & 18.98 & 13.14 \\
\hline $\mathrm{N}$ fertilizer & & 0 & 9 & & 0.0 & 0.0 & 607.95 \\
\hline Production & & & & & & & \\
\hline $\mathrm{N}$ fertilizer & & 0 & 9 & & 0.0 & 0.0 & $7.56^{\mathrm{b}}$ \\
\hline Application & & & & & & & \\
\hline $\begin{array}{l}\text { Harvesting (cut and } \\
\text { chip harvesting) }\end{array}$ & & 12 & 8 & & $5.16-9.60$ & $5.16-9.60$ & $3.44-6.40$ \\
\hline $\begin{array}{l}\text { Natural drying \& storage } \\
\text { (approximately the same } \\
\text { for first } 30 \text { tonnes) }\end{array}$ & & 12 & 8 & & $3.84-4.80$ & $3.84-4.80$ & $2.56-3.20$ \\
\hline Transport $(15 \mathrm{~km})$ & 25 & 12 & 8 & 27 & 12.96 & 12.96 & 8.64 \\
\hline Termination & & 1 & 1 & & 6.65 & 6.65 & 6.65 \\
\hline Total energy input & & & & $47-53.5$ & $37.78-43.62$ & $56.76-62.60$ & $659.11-663.15$ \\
\hline Total energy return ${ }^{c}$ & & & & $776.5-1745$ & 662.4-1821.6 & $828-2278$ & $648-1783$ \\
\hline EROEI & & & & $16.5-32.6$ & $17.5-41.8$ & $14.6-36.4$ & $1.0-2.7$ \\
\hline Net Energy Gain NEG & & & & $729.5-1691.5$ & $624.6-1778.0$ & $771.2-2215.4$ & -11.1 to 1119.8 \\
\hline
\end{tabular}

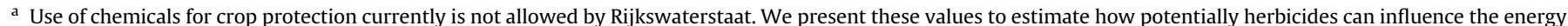
efficiency of the whole system.

b Harvesting cycle is 2 or 3 years and only one herbicide and fertilizer application takes place during a harvesting cycle.

${ }^{c}$ The lower value corresponds to electricity only option, the higher is for combined heat and electricity generation.

for A roads there is approximately $1.02-1.62 \mathrm{ha} / \mathrm{km}$ that are currently unconditionally available for willow biomass production, while another $2.61-3.66 \mathrm{ha} / \mathrm{km}$ or a total of $4.24-4.68 \mathrm{ha} / \mathrm{km}$ may be available if some changes are made to the current regulations. For $\mathrm{N}$ roads the values are much lower, but the range is much larger: $0.37-0.80 \mathrm{ha} / \mathrm{km}$ and $0.43-1.88$, respectively, or a total of

Table 8

EROEI estimates for various energy sources. Note that the results largely depend upon the boundaries of the study and the assumptions that go into the calculations. The relatively high EROEI values registered in this study are largely explained by the fact that we are relying on existing energy producing and distribution infrastructure (Twence plant).

\begin{tabular}{|c|c|c|}
\hline Energy source & EROEI & Reference \\
\hline Natural gas & $20-67$ & Hall et al., 2014 \\
\hline Oil (1930) & $>100$ & Cleveland, 2005 \\
\hline $\begin{array}{l}\text { Oil and gas } \\
\qquad(1970-2005)\end{array}$ & $12-30$ & $\begin{array}{l}\text { Cleveland et al., 1984; } \\
\text { Hall et al., } 2014\end{array}$ \\
\hline Coal & $27-80$ & Hall et al., 2014 \\
\hline Nuclear & $5-15$ & Hall et al., 2014 \\
\hline Hydropower & $>100$ & Hall et al., 2014 \\
\hline Wind & $15-18$ & $\begin{array}{l}\text { Hall et al., 2014; } \\
\text { Murphy and Hall, } 2010\end{array}$ \\
\hline $\begin{array}{l}\text { Road verge grass } \\
\text { for biogas }\end{array}$ & $2-3$ & Meyer et al., 2014 \\
\hline $\begin{array}{l}\text { Leaf fall and organic } \\
\text { waste }\end{array}$ & $6-15$ & Arodudu et al., 2014 \\
\hline $\begin{array}{l}\text { Switchgrass or miscantus } \\
\text { on urban lots }\end{array}$ & $3-14$ & Arodudu et al., 2014 \\
\hline Rapeseed for biodiesel & 2 & Firrisa et al., 2013 \\
\hline Biogas from crop residue & $5-17$ & Arodudu et al., 2013 \\
\hline $\begin{array}{l}\text { Road verge willow for } \\
\text { electric and heat } \\
\text { cogeneration }\end{array}$ & $18-42$ & This study \\
\hline $\begin{array}{l}\text { Road verge grass for electric } \\
\text { and heat cogeneration }\end{array}$ & $17-33$ & This study \\
\hline
\end{tabular}

0.80-2.67 ha/ $\mathrm{km}$. One possible explanation for a much wider variability we saw for $\mathrm{N}$ roads is because N35 was at some point designed as an extension of A35 and therefore has larger verge areas than one would expect to see on regular $\mathrm{N}$ roads. The N18 seems to be a more typical $\mathrm{N}$-road and the amount of verge it produces is probably a more useful estimate if we want to use this to expand our analysis beyond the study area for other roads. In what follows we have assumed that biomass is produced at that productivity uniformly along the span of each corresponding road segment.

The feasibility of generating energy (electricity) from roadside biomass (verge grass and willow SRC) can be discussed in the context of resource and environmental constraints. We are deliberately ignoring the issues of economic, monetary accounting and profitability because there is too much uncertainty and volatility in the renewable energy market so largely influenced by subsidies and fossil fuel prices.

The large difference between road verge area conditionally ( $168.58 \mathrm{ha}$ ) and unconditionally available ( $70.63 \mathrm{ha}$ ) along roads A1, A35, N18 and N35 indicates that there is great opportunity in utilizing conditionally available road verge for bioenergy production. As a matter of fact, from the land use map of the study area, the area under forest in eastern Overijssel is $102.47 \mathrm{~km}^{2}$, but only about $1.6 \%$ of it is roadside forest. Although roadside trees thicker than $8 \mathrm{~cm}$ are under protection by the Dutch Forest Act (Rijkswaterstaat, 2008), it is suggested that other larger areas of forest farther away from the roads are actually better positioned for the protection of valuable or vulnerable species than those close to the roadside due to the frequency and intensity of disturbance. Conditionally available land is larger than unconditionally available land and more efforts are required to remove the current vegetation (usually trees), therefore, the use of conditionally available land needs more careful management. On the other hand, the soils 
Table 9

Area and length calculations for the roads considered in this study. The unconditionally available land is substantially less than what may become available if certain environmental and land use constraints are lifted.

\begin{tabular}{lrllll}
\hline $\begin{array}{l}\text { Road } \\
\text { name }\end{array}$ & $\begin{array}{l}\text { Road } \\
\text { length } \\
(\mathrm{km})\end{array}$ & $\begin{array}{l}\text { Cond_Avail. } \\
\text { Area } \\
\text { (ha) }\end{array}$ & $\begin{array}{l}\text { Cond_Avail. } \\
\text { Area } \\
\text { (ha/km) }\end{array}$ & $\begin{array}{l}\text { Total_Uncond_ } \\
\text { Avail._Area } \\
\text { (ha) }\end{array}$ & $\begin{array}{l}\text { Uncond_Avail. } \\
\text { Area } \\
\text { (ha/km) }\end{array}$ \\
\hline A1 & 27.12 & 99.22 & 3.66 & 27.69 & 1.02 \\
A35 & 19.51 & 51.01 & 2.61 & 31.69 & 1.62 \\
N18 & 18.36 & 7.90 & 0.43 & 6.82 & 0.37 \\
N35 & 5.57 & 10.45 & 1.88 & 4.43 & 0.80 \\
Total A & 46.63 & & & & \\
Total N & 23.93 & & & 70.63 & \\
Total & & 168.58 & & & \\
\hline
\end{tabular}

of conditionally available land are loamy because of the previous presence of trees, rich in organic matter and nitrogen, and it is better for willow development (Mortensen et al., 1998). In this vein, exploring conditionally available road verge can be said to be quite feasible. Also, 10 ha is considered the minimum operational scale for the establishment of willow SRC (Abrahamson et al., 2002). Consequently, it can be concluded that the production of willow biomass on available road verges in the study area is feasible in terms of land availability.

In the Netherlands, the total biomass production in natural fields is around $3 \times 10^{6} \mathrm{odt} / \mathrm{yr}^{1}, 1.7 \times 10^{6} \mathrm{odt} / \mathrm{yr}$ of which is contributed by forests and approximately $1 \times 10^{6} \mathrm{odt} / \mathrm{yr}$ from grassland. Due to conservation of biodiversity, only about $1.9-2.3 \times 10^{6} \mathrm{odt} / \mathrm{yr}$ of the total amount of biomass can be harvested annually (Spijker et al., 2007). The estimated biomass production on available road verge in the study area is relatively small compared to provincial and national demands (Table 10), and is within the capacity of the biomass processing power plant Twence, which can convert about $140 \times 10^{3} \mathrm{odt} / \mathrm{yr}$. The slight increase of biomass input for the Twence biomass power plant will not become a burden; it will only increase the green electricity production for the Province.

Road verges can be mostly considered as wasteland. They are quite heavily polluted by depositions from fuel combustion, as well as potential garbage and hazardous substances coming from transportation. They are also under intense disturbance due to noise, light and motion of traffic. As such their natural conservation value is quite low. There is increasing interest in producing bioenergy from waste, crop residue and by-products (Arodudu et al., 2013). There are also programs in place that focus on using contaminated and disturbed lands to produce bioenergy (http:// biomassmagazine.com/articles/5955/epa-doe-to-study-

contaminated-lands-for-bioenergy-potential). As such road verge can be very well considered in the same category.

The fact that these areas are already under heavy maintenance certainly is important to consider when doing the overall estimates. Unlike the biomass production on natural grasslands and abandoned pasturelands considered by Arodudu et al. (2013) the production on road verge will be much cheaper and energy efficient because it can be largely handled within the operations already stipulated by the existing road maintenance regulations. The proximity to the road network and ease of access are the other factors that need to be taken into consideration.

\footnotetext{
1 odt - oven dry ton. 1 ton DM is not very different from odt; odt is also known as US tons. odt $=1000.5 \mathrm{~kg}$; while ton $\mathrm{DM}=1000 \mathrm{~kg}$. Since there is no significant difference we will be using both units interchangeably.
}

\section{Conclusions and recommendations}

In eastern Overijssel, the amount of land available for willow SRC cultivation along A1, A35, N18 and N35 roads is about 239.21 ha. However only 70.63 ha can be used without any ecological or land use concerns. If we can prove that stripes of willow are actually better serving the purposes of land use, conservation, and, in some cases, road safety than grasslands, then we can considerably increase the size of area available for its production.

Four alternative management options for bioenergy production on estimated available road verge were considered, in addition to the reference option, which is currently used and which requires grass to be mowed and then composted. Other options considered assume gasification of verge grass, and four willow cultivation options that are studied for different available area sizes, fertilizer and herbicide inputs, and rotation lengths. The comparison of EROEI shows that willow cultivation on road verge, without any application of fertilizer or herbicide has the best energy performance. While this study recommends this management option, it is still not as efficient as common commercial cultivation of willow. However, if the energy input of the reference system (mowing and transporting verge grass twice a year) is considered as a baseline, it would actually become an energy and cost saving venture for Rijkswaterstaat and municipal authorities, which currently are in charge of verge management in the Netherlands, but for whom it remains a cost rather than a revenue source.

With this paper we are continuing our quest for alternative sources of bio-energy that are in no conflict with agriculture or nature. We have previously considered urban, built-up areas (Arodudu et al., 2014); here we focus on areas that are available along the roads. Although the available road verge, biomass production, and energy generation even from the best willow cultivation option are not significant comparing to the national or even provincial level in the Netherlands, the idea of making use of the Dutch roads is definitely feasible from the perspectives of resource conservation. It is also very likely to be beneficial from the financial and environmental viewpoints. The presently unused road verge can be easily turned into a feedstock for biomass, producing additional energy and financial gains. This kind of bioenergy production should therefore be accorded attention, its marginal contribution notwithstanding. In the event of an acute shortage and further depletion of the Earth's fossil fuel resources and supplies, and an eventual need for stronger commitments to the implementation of climate change mitigation options, road verges might end up being a valuable contributor to ensuring energy sustainability by complementing other renewable energy sources in the energy mix. Certainly a comprehensive Life Cycle Impact Assessment, taking into account other main damage categories (climate change, resources, ecosystem quality, human health) will be required before final decisions are made, however here we already see that from the energy efficiency (EROEI) point of view the scenarios of low input willow and grass production can be feasible and beneficial for the energy system of Overijssel province.

Switching to alternative energy sources and developing policies that would promote them is not going to be easy. Even if we know the stakes and benefits involved in such transitions, translating them into action is not straightforward and may require additional research of the decision making processes, perhaps applying such techniques as co-evolutionary games (Perc \& Szolnoki, 2010), agent based modeling (Filatova et al., 2013) and participatory modeling (Voinov \& Bousquet, 2010).

For now what we find is that with $137,000 \mathrm{~km}$ of roads, Netherlands is poised to be able to produce quite significant amounts of biomass for energy if road verge is harvested. Assuming 


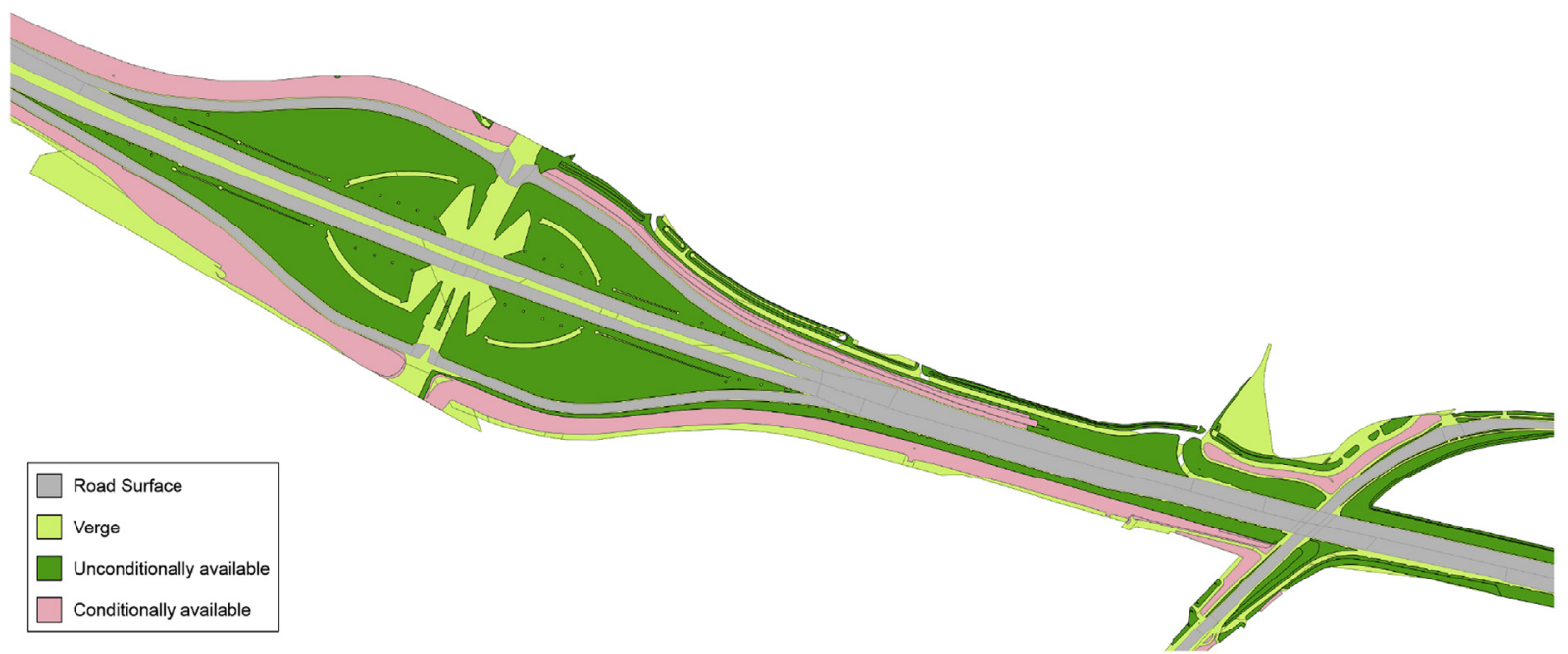

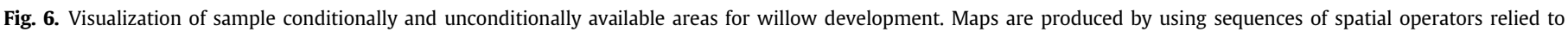
various conditional statements and applied to the cadastral data.

Table 10

Biomass production from verge grass and cultivation options for willow SRC for the analyzed roads.

\begin{tabular}{|c|c|c|c|c|}
\hline Cultivation option & Reference & 1 & 2 & 3 \\
\hline $\begin{array}{l}\text { Yield (t/ha/year) } \\
\quad \text { (Table 6) }\end{array}$ & 8 & 16 & 20 & 24 \\
\hline $\begin{array}{l}\text { Annual yield } \\
\text { (odt/yr/ha) }\end{array}$ & 0.32 & 0.64 & 0.8 & 0.96 \\
\hline $\begin{array}{l}\text { Annual yield on } \\
\text { unconditional } \\
\text { areas (odt/yr) }\end{array}$ & 565.06 & 1130.13 & 1412.66 & 1695.19 \\
\hline $\begin{array}{l}\text { Annual yield on total } \\
\text { (unconditional and } \\
\text { conditional) areas } \\
\text { (odt/yr) }\end{array}$ & 1913.72 & 3827.44 & 4784.29 & 5741.15 \\
\hline NEG max (total) (GJ/yr) & 129482 & 272207 & 423965 & 257158 \\
\hline NEG min (total) (GJ/yr) & 55842 & 95625 & 147586 & -2549 \\
\hline
\end{tabular}

the very conservative estimate of verge area per ha in Table 9 we can calculate that if the entire unconditionally available road verge is used for bioenergy production we can expect that some 50-177 PJ can be produced annually, depending upon the cultivation and processing technology chosen. This number can go up to $149-527 \mathrm{PJ}$ if the conditionally available road verge is brought into the production. This can already be a substantial part of the 2.1 EJ estimated as minimum target of renewable energy production by the year 2020; and perhaps even provide all of the $54.5 \%$ that is expected to be from biomass sources ( $0.30 \mathrm{EJ}$ ) (Atanasiu, 2010). It is also very promising that all this energy can be produced with relatively high efficiencies (Table 8 ) and at no additional social and environmental costs for the society.

\section{Acknowledgments}

A. Voinov was partially supported by the BE2.O (Bioenergy for Overijssel) project and by the EU-FP7-308601 COMPLEX project. Funding from the Erasmus Mundus program was instrumental in supporting Ling Qin and Oludunsin Arodudu. Our thanks are also due to Arjan Reuver (Assistant Maintenance Manager, RWS East Netherlands), Hans Nieuwenhuis (Project manager of De Jong en Zoon Beesd BV), Guido Debeus (Manager of Division Innovation \& Implementation, Dienst Verkeer en Scheepvaart), J. W. Slijkhuis (Roads and Waterways Management, Province Overijssel and to personnel from Rijkswaterstaat East Netherlands for providing important insight about the current road verge management practices.

\section{References}

Abrahamson, L.P., Volk, T.A, Kopp, R.F., White, E.H., Ballard, J.L, 2002. Willow Biomass Producer's Handbook. State University of New York, College of Environmental Science and Forestry, Syracuse, NY.

AEA Energy and Environment, 2008. Biomass Environmental Assessment Tool Version 2 User Guide. DEFRA, Biomass Energy Centre, Environment Agency, UK.

Arodudu, O.T., Voinov, A., van Duren, I., 2013. Assessing bioenergy potentials in rural areas. Biomass Bioenergy 58 (38), 350-364. http://dx.doi.org/10.1016/j. biombioe.2013.07.020.

Arodudu, O.T., Ibrahim, E.S., Voinov, A., van Duren, I., 2014. Exploring bioenergy potentials of built-up areas based on NEG-EROEI indicators. Ecol. Indic. http:// dx.doi.org/10.1016/j.ecolind.2014.04.042.

Atanasiu, B., 2010 Nov.. The Role of Bioenergy in the National Renewable Energy Action Plans: a First Identification of Issues and Uncertainties. Institute for European Environmental Policy (IEEP), Bonn (Germany), p. 23.

Basu, P., 2010. Definition of Biomass. Biomass Gasification Design Handbook. Academic Press, Boston.

Berglund, M., Börjesson, P., 2006. Assessment of energy performance in the lifecycle of biogas production. Biomass Bioenergy 30, 254-266.

Boosten, M., 2009. Poster: 'Short Rotation Coppice (SRC) in the Netherlands'. International Energy Farming Congress, Papenburg, Germany.

Börjesson, P.I.I., 1996. Energy analysis of biomass production and transportation. Biomass Bioenergy 11, 305-318.

Börjesson, P., Mattiasson, B., 2008. Biogas as a resource-efficient vehicle fuel. Trends Biotechnol. 26, 7-13.

Börjesson, P., Tufvesson, L.M., 2011. Agricultural crop-based biofuels - resource efficiency and environmental performance including direct land use changes. J. Clean. Prod. 19 (2-3), 108-120. http://dx.doi.org/10.1016/j.jclepro.2010.01.001.

Borst, R.H.J., Sprong, R., 2006. GEDRAGSCODE: Bestendig beheer groenvoorzieningen (Code of Green Management Service). Vereniging Stadswerk Nederland, Vakgroep Groen, Natuur en Landschap Vereniging van Hoveniers en Groenvoorzieners (VHG), The Netherlands.

Bridgewater, A.V., 2001. Thermal conversion of Biomass and Waste: the Status. BioEnergy Research Group. Aston University, Birmingham (UK).

Bridgewater, A.V., Peacocke, G.V.C., 2000. Fast pyrolysis processes for biomass. Renew. Sustain Energy Rev. 4, 1-73.

Bussel, L.V., 2006. The Potential Contribution of a Shortrotation Willow Plantation to Mitigate Climate Change. Msc thesis. Wageningen University, The Netherlands.

Caslin, B., Finnan, J., McCracken, A. (Eds.), 2010. Short Rotation Coppice Willow Best Practice Guidelines: Teagasc. Crops Research Centre, Oak Park, Carlow: AFBI, Agri-Food and Bioscience Institute, Newforge Lane, Belfast.

Central Bureau of Statistics, 2009. Renewable Energy in the Netherlands 2008. The Hague.

Central Bureau of Statistics, 2011. Traffic and Transport [Online]. Available: http:// www.cbs.nl/en-GB/menu/themas/verkeer-vervoer/nieuws/default.htm [accessed 01.01.11]. 
Ceulemans, R., McDonald, A.J.S., Pereira, J.S., 1996. A comparison among eucalypt, poplar and willow characteristics with particular reference to a coppice, growth-modelling approach. Biomass Bioenergy 11, 215-231.

Cleveland, C.J., 2005. Net energy from oil and gas extraction in the United States, 1954-1997. Energy 30, 769-782.

Cleveland, C.J., Costanza, R., Hall, C.A.S., Kaufmann, R., 1984. Energy and the U.S. Economy: a biophysical perspective. Science 225, 890-897.

Cuperus, R., Canters, K.J., Piepers, A.A.G., 1996. Ecological compensation of the impacts of a road. Preliminary method for the A50 road link (Eindhoven-Oss, The Netherlands). Ecol. Eng. 7, 327-349.

DEFRA, 2004. Growing Short Rotation Coppice. Best Practice Guidelines for Applicants to DEFRA's Energy Crops Scheme. Department for Environment, Food and Rural Affairs, UK.

Demirbaş, A., 2005. Potential applications of renewable energy sources, biomass combustion problems in boiler power systems and combustion related environmental issues. Prog. Energy Combust. Sci. 31, 171-192.

Demirbaș, A., 2007. Progress and recent trends in biofuels. Prog. Energy Combust. Sci. 33, 1-18.

Eck, R.W., McGee, H.W., 2008. Vegetation Control for Safety, a Guide for Local Highway and Street Maintenance Personnel. Vanasse Hangen Brustlin Inc, Vienna, VA.

Encyclopedia of the Nations, 2007. Road density ( $\mathrm{km}$ of road per sq. km of land area) - Transportation - Infrastructure - World Development Indicators. Encyclopedia of the Nations. Advameg, Inc.

Energy Research Centre of the Netherlands, 1998. Phyllis Database on the Composition of Biomass and Waste. Energy research Centre of the Netherlands.

Europe's Energy Portal, 2010. Statistics of Renewables: 2006-2010 [Online]. Available: http://www.energy.eu/\#renewable [accessed 12.08.10].

European Commission, 2007. MEMO/07/8: Aiming towards a Low CO2 Fossil Fuel Future. European Communities, Brussels.

European Parliament \& European Council, 2009. Directive 2009/28/EC on the Promotion of the Use of Energy from Renewable Sources and Amending and Subsequently Repealing Directives 2001/77/EC and 2003/30/EC. European Commission, Brussels,

Faaij, A., van Doorn, J., Curvers, T., Waldheim, L., Olsson, E., Van Wijk, A., Daey-Ouwens, C., 1997. Characteristics and availability of biomass waste and residues in The Netherlands for gasification. Biomass Bioenerg. 12, 225-240.

Faaij, A., Meuleman, B., Turkenburg, W., van Wijk, A., Ausilio, B., Rosillo-Calle, F., Hall, D., 1998. Externalities of biomass based electricity production compared with power generation from coal in the Netherlands. Biomass Bioenerg. 14, 125-147.

Filatova, T., Verburg, P.H., Parker, D., Stannard, C.A., July 2013. Spatial agent-based models for socio-ecological systems: challenges and prospects. Environ. Model. Softw. 45, 1-7. http://dx.doi.org/10.1016/j.envsoft.2013.03.017.

Firrisa, M.T., van Duren, I., Voinov, A., 2013. Energy efficiency for rapeseed biodiesel production in different farming systems. Energy Effic. http://dx.doi.org/10.1007/ s12053-013-9201-2 (April 12).

Fischer, G., Prieler, S., van Velthuizen, H., Lensink, S.M., Londo, M., de Wit, M., 2010. Biofuel production potentials in Europe: sustainable use of cultivated land and pastures. Part I: land productivity potentials. Biomass Bioenergy 34, 159-172.

Gigler, J.K., Meeusen-van Onna, M.J.G., Annevelink, E. (Eds.), 1999. Kansen voor energie uit biomassa! Resultaten van een 4-jarig DLO-onderzoekprogramma. Dienst Landbouwkundig Onderzoek, Wageningen.

Gommers, A., Gäfvert, T., Smolders, E., Merckx, R., Vandenhove, H., 2005. Radiocaesium soil-to-wood transfer in commercial willow short rotation coppice on contaminated farm land. J. Environ. Radioact. 78, 267-287.

González-García, S., Moreira, M.T., Dias, A.C., Mola-Yudego, B., 2014. Cradle-to-gate life cycle assessment of forest operations in Europe: environmental and energy profiles. J. Clean. Prod. 66, 188-198. http://dx.doi.org/10.1016/j.jclepro. 2013.11.067.

Gray, K.A., Zhao, L., Emptage, M., 2006. Bioethanol. Curr. Opin. Chem. Biol. 10, $141-146$.

Grisso, R., Perumpral, J.V., Vaughan, D., Roberson, G.T., Pitman, R., 2010. Predicting Tractor Diesel Fuel Consumption. Virginia Cooperative Extension, Virginia Tech, Virginia State University, 442-073.

Haines-Young, R.H., Barr, C.J., Black, H.I.J., Briggs, D.J., Bunce, R.G.H., Clarke, R.T. Cooper, A., Dawson, F.H., Firbank, L.G., Fuller, R.M., Furse, M.T., Gillespie, M.K., Hill, R., Hornung, M., Howard, D.C., McCann, T., Morecroft, M.D., Petit, S., Sier, A.R.J., Smart, S.M., Smith, G.M., Stott, A.P., Stuart, R.C., Watkins, J.W., 2000. Accounting for Nature: Assessing Habitats in the UK Countryside. Department of the Environment, Transport and the Regions, London.

Hall, C.A.S., Lambert, J.G., Balogh, S.B., 2014. EROI of different fuels and the implications for society. Energy Policy 64, 141-152. Available at: http://dx.doi.org/10. 1016/j.enpol.2013.05.049.

Hall, C.A.S., Balogh, S., Murphy, D.J.R., 2009. What is the minimum EROI that a sustainable society must have? Energies 2 (1), 25-47.

Harwood, D., Mason, J., Brydia, R., Joubert, H., Lamm, R., Psarianos, B., 1995. International sight distance design practices. In: Proceedings of the International Symposium on Highway Geometric Design Practices. Boston, MA, USA.

Harwood, D.W., Mason, J.M., Brydia, R.E., April 1999. Design policies for sight distance at stop-controlled intersections based on gap acceptance. Transp. Res. Part A: Policy Pract. 33 (3-4), 199-216. http://dx.doi.org/10.1016/S09658564(98)00040-8.

Heller, M.C., Keoleian, G.A., Volk, T.A., 2003. Life cycle assessment of a willow bioenergy cropping system. Biomass Bioenergy 25, 147-165.
Huang, B.K., 1987. Dynamic simulation of a vehicle interaction with biological and physical systems. In: American Control Conference, 1987. Minneapolis, MN, USA.

Huisman, W., 2003. Optimising harvesting and storage systems for energy crops in The Netherlands. In: International Conference on Crop Harvesting and Processing. Louisville, Kentucky, USA.

Jenkins, B.M., Baxter, I.L., Miles, T.R., 1998. Combustion properties of biomass. Fuel Process. Technol. 54, 17-46.

Kim, S., Dale, B.E., 2005. Life cycle assessment of various cropping systems utilized for producing biofuels: bioethanol and biodiesel. Biomass Bioenerg. 29, 426-439.

Kuiper, L., 2003. Samenvatting van de resultaten van zes jaar onderzoek naar energieteelt Centrum voor Biomassa Innovatie. Wageningen.

Kumar, G., Bakonyi, P., Periyasamy, S., Kim, S.H., Nemestóthy, N., Bélafi-Bakó, K., 2015. Lignocellulose biohydrogen: practical challenges and recent progress. Renew. Sustain. Energy Rev. 44, 728-737. http://dx.doi.org/10.1016/ j.rser.2015.01.042.

Lechasseur, G., Savoie, P., 2005. In: . Cutting, Bundling and Chipping Short-rotation willow. CSAE/SCGR 2005 Meeting. Winnipeg, Manitoba, Canada.

Lettens, S., Muys, B., Ceulemans, R., Moons, E., Garcia, J., Coppin, P., 2003. Energy budget and greenhouse gas balance evaluation of sustainable coppice systems for energy production. Biomass Bioenerg. 24, 179-197.

Londo, H.M., 2002. Energy Farming in Multiple Land Use: an Opportunity for Energy Crop Introduction in the Netherlands. Ph.D. thesis. Utrecht University.

Londo, M., Roose, M., Dekker, J., de Graaf, H., 2004. Willow short-rotation coppice in multiple land-use systems: evaluation of four combination options in the Dutch context. Biomass Bioenergy 27, 205-221.

Luque, R., Herrero-Davila, L., Campelo, J.M., Clark, J.H., Hidalgo, J.M., Luna, D. Marinas, J.M., Romero, A.A., 2008. Biofuels: a technological perspective. Energy \& Environ. Sci. 1, 542-564.

Matthews, R., 2001. Modelling of energy and carbon budgets of wood fuel coppice systems. Biomass Bioenergy 21, 1-19.

McKendry, P., 2002a. Energy production from biomass (part 1): overview of biomass. Bioresour. Technol. 83, 37-64.

McKendry, P., 2002b. Energy production from biomass (part 2): conversion technologies. Bioresour. Technol. 83, 47-54.

Meyer, A.K.P., Ehimen, E.A., Holm-Nielsen, J.B., 2014. Bioenergy production from roadside grass: a case study of the feasibility of using roadside grass for biogas production in Denmark. Resour. Conserv. Recycl. 93, 124-133. http://dx.doi.org/ 10.1016/j.resconrec.2014.10.003.

Ministerie van, L.N.V., 2000. Uitvoering Boswet Rijkswaterstaat. Ministerie van LNV, Den Haag.

Mortensen, J., Hauge Nielsen, K., Jørgensen, U., 1998. Nitrate leaching during establishment of willow (Salix viminalis) on two soil types and at two fertilization levels. Biomass Bioenerg. 15, 457-466.

Murphy, D.J., Hall, C.A.S., 2010. Year in review-EROI or energy return on (energy) invested. Ann. York Acad. Sci. 1185, 102-118. Available at: http://www.ncbi.nlm. nih.gov/pubmed/20146764.

Nguyen, T.L.T., Hermansen, J.E., Nielsen, R.G., 2013. Environmental assessment of gasification technology for biomass conversion to energy in comparison with other alternatives: the case of wheat straw. J. Clean. Prod. 53, 138-148. http:// dx.doi.org/10.1016/j.jclepro.2013.04.004.

Ni, M., Leung, D.Y.C., Leung, M.K.H., Sumathy, K., 2006. An overview of hydrogen production from biomass. Fuel Process. Technol. 87, 461-472.

Nordh, N.E., Dimitriou, I., 2003. Harvest Techniques in Europe. Short Rotation Crops for Bioenergy. New Zealand.

Ölz, S., Sims, R., Kirchner, N., 2007. Contribution of Renewables to Energy Security Renewable Energy Working Party. International Energy Agency.

Provincie Overijssel, 2010. Vlotte en veilige kruispunten (Safe intersections) [Online]. Available: http://www.overijssel.nl/thema's/bereikbaar/overijssel-doet/ vlotte-veilige/ [accessed 06.12.10].

Perc, M., Szolnoki, A., 2010. Coevolutionary games - a mini review. BioSystems 99, 109-125. http://dx.doi.org/10.1016/j.biosystems.2009.10.003.

Petersson, A., Thomsen, M.H., Hauggaard-Nielsen, H., Thomsen, A.B., 2007. Potential bioethanol and biogas production using lignocellulosic biomass from winter rye, oilseed rape and faba bean. Biomass Bioenergy 31, 812-819.

Ponton, J.W., 2009. Biofuels: thermodynamic sense and nonsense. J. Clean. Prod. 17, 896-899.

Ramstedt, M., 1999. Rust disease on willows - virulence variation and resistance breeding strategies. For. Ecol. Manag. 121, 101-111.

Rijkswaterstaat \& Dienst Weg- en Waterbouwkunde, 2006. Leidraad beheer groenvoorzieningen (Green management guidance). Ministerie van Verkeer en Waterstaat, Amsterdam.

Rijkswaterstaat, 2008. Overzicht van de vegetatie langs Rijkswegen (Overview of the vegetation along National Road). Ministerie van Verkeer en Waterstaat, Amsterdam.

Schepers, J.A.M., Haperen, A.A.M., van der Jagt, J.L.E., 1992. Grienden: hakken of laten groeien: inventarisatie van het hakgriendenareaal en mogelijkheden voor ontwikkeling (Traditional willow coppice: coppicing or letting grow; an inventory of the arsenal of traditional willow coppice and potentials for development). Utrecht, IKC-NBLF.

Spijker, J.H., Elbersen, H.W., Jong, J.J.D., Berg, C.A.V.D., Niemeijer, C.M., 2007. Biomassa voor energie uit de Nederlandse natuur : een inventarisatie van hoeveelheden, potenties en knelpunten (Biomass energy from the Dutch nature: an inventory of amounts, and potential bottlenecks). Biobased Products, Centrum Landschap, Wageningen. 
Staatsuitgeverij, 1986. Richtlijnen Voor Het Ontwerpen Van Niet-Autoschnellwegen Buiten de Bebouwde Kom. In: KRESIPUNTEN. Staatsuitgeverij, Hague.

Truscott, A.M., Palmer, S.C.F., McGowan, G.M., Cape, J.N., Smart, S., 2005. Vegetation composition of roadside verges in Scotland: the effects of nitrogen deposition disturbance and management. Environ. Pollut. 136, 109-118.

Tubby, L., Armstrong, A., 2002. Establishment and management of short rotation coppice. In: Forest Commission. Edinburgh, UK.

Twence, 2009. Sustainability Report. Hengelo.

van der Heijden, L.A.M., Martens, M.J.M., 1982. Traffic noise reduction by means of surface wave exclusion above parallel grooves in the roadside. Appl. Acoust. 15, 329-339.

van Duren, I., Voinov, A., Arodudu, O.T., Firissa, M.T., 2015. Where to Produce Rapeseed Biodiesel and Why? Mapping European RME Energy Efficiency in Different Agro-ecological Conditions. http://dx.doi.org/10.1016 j.renene.2014.07.016.

Van Strien, W. Tabak, A. van den Hengel, B., Cuperus, R. Viering, J. 2005. Beheerskosten en natuurwaarden van groenvoorzieningen langs wegen. DWWrapport nr DWW-2005-078. Dienst Weg- en Waterbouwkunde, Delft, ISBN 90369-5603-X.

Visser, H., 2010. Total Length Dutch Roads Stretches Halfway to the Moon [Online] Statisitcs Netherlands. Available: http://www.cbs.nl/en-GB/menu/themas/ dossiers/nederland-regionaal/publicaties/artikelen/archief/2010/2010-3247wm.htm?RefererType=RSSItem\&RSSFeedTitle=Bevolking [accessed 24.11.10].

Voinov, A., Bousquet, F., 2010. Modelling with stakeholders. Environ. Model. Softw. 25 (May), 1268-1281. http://dx.doi.org/10.1016/j.envsoft.2010.03.007.

Volk, T.A., Verwijst, T., Tharakan, P.J., Abrahamson, L.P., White, E.H., 2004. Growing fuel: a sustainability assessment of willow biomass crops. Front. Ecol. Environ. 2, $411-418$.

Volk, T.A., Buchholz, T., Castellano, P., Abrahamson, L., Smart, L., 2009. Year. Woody biomass from forests and Fields. In: Heating the Northeast. Nashua, NH. SUNYESF, Syracuse, NY. April 29-30 2009.

Vollebergh, H., 1997. Environmental externalities and social optimality in biomass markets: waste-to-energy in The Netherlands and biofuels in France. Energy Policy 25, 605-621.

Warren, R.S., Birch, P., 1987. Heavy metal levels in atmospheric particulates, roadside dust and soil along a major urban highway. Sci. Total Environ. 59, 253-256.

Weih, M., 2004. Intensive short rotation forestry in boreal climates: present and future perspectives. Can. J. For. Res. 34, 1369-1378.

Zuwala, J., 2012. Life cycle approach for energy and environmental analysis of biomass and coal co-firing in CHP plant with backpressure turbine. J. Clean. Prod. 35, 164-175. http://dx.doi.org/10.1016/j.jclepro.2012.06.001. 